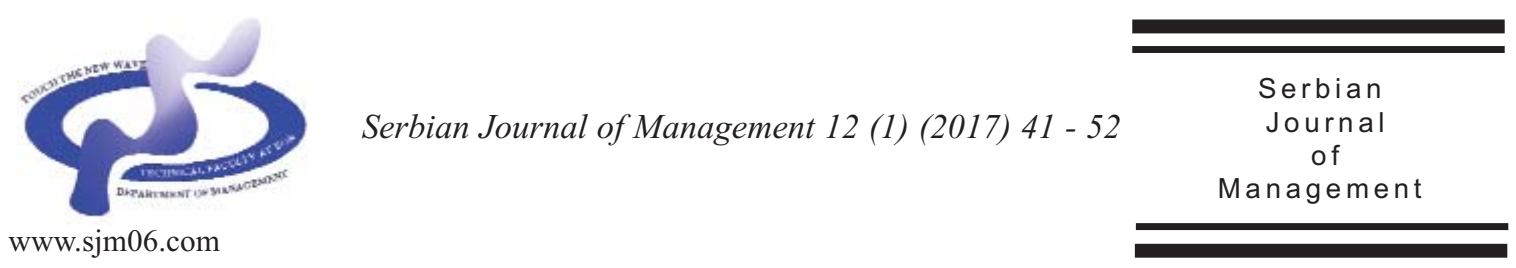

\title{
THE IMPACT OF TRAINING ON OPERATIONAL PERFORMANCE: THE CASE OF THE CUSTOMS SERVICE AT NIKOLA TESLA AIRPORT IN BELGRADE
}

\author{
Sanja Dalton* \\ University of Belgrade, Faculty of Organizational Sciences, \\ Jove Ilića 154, Belgrade, Serbia
}

(Received 21 March 2016; accepted 19 September 2016)

\begin{abstract}
In this paper the impact of risk analysis and assessment training of the customs officers on improvement of their operational performances at Nikola Tesla airport in Belgrade is presented. The aim of the research is to measure the perception of the customs officers at the airport about the operational effectiveness of the risk analysis training program. The research was conducted through survey, by collecting data from the questionnaire disseminated to the customs officers who were divided into experimental (the officers who attained the training) and control group (the officers who have not attained the training). Both groups of the officers evaluated the statements about their performance contribution in effective collection of revenue, facilitation of trade and passengers, border control and protection level and reputation of the customs unit at the airport. The results of the research show that there is a significant difference between the groups, which confirms the hypothesis that the risk analysis and assessment training has a positive impact on the customs officers' operational efficiency.
\end{abstract}

Keywords: Training, operational performance, risk analysis, customs service.

\section{INTRODUCTION}

In this study we investigated the relationship of HRM best practices in enhancing organization performance (Beh \& Loo, 2013). The customs services at border crossings are dealing with those operations

$$
\begin{aligned}
& \text { and activities that require constant } \\
& \text { development of skills, know-how and } \\
& \text { practical experience in order to successfully } \\
& \text { keep the balance between the increasing } \\
& \text { trade and passengers' turnover and at the } \\
& \text { same time decreasing of (human) resources } \\
& \text { in order to attain high standards in }
\end{aligned}
$$

\footnotetext{
* Corresponding author:sanjadalton78@gmail.com
}

DOI: $10.5937 /$ sjm12-10539 
operational performances. Human resource management department of the Customs Administration of Serbia plays a main role in the management practices which creates, develops and manages the human element of the customs service. According to Niazi (2011), the value of training cannot be ruled out in all phases of human resources development of any border enforcement agency, due to dynamic changes the operational staff have to cope with. There have been a numerous studies by various authors for a long time, demonstrating that there are sound associations amongst training practices and distinct measures of operational staff performance within an organization intended to improve the performance of employees (Niazi, 2011). Hence, human resource personnel should focus on how to develop and sustain its human resource through effective HTM best practices to enhance current and future performance of the organization (Beh \& Loo, 2013).

The operational performances of the border customs officers are considered as the major element of the Customs administration of Serbia and the overall success and failure in the operational results are mainly based on their performance (Hameed, 2011). It is proved that enforcement organizations generally spend more in training in contrast with other organizations because training aids staff to acquire the practical and operational knowledge and skills that can be not acquired by academic information.

The 100 per cent checks of passengers and commodities at borders are not feasible any longer, that does not allow detailed check due to insufficient time per a check that causes delay of the trade and passengers that impedes the control and protection level that results in irregularities of collection of the revenues and the overall border protection level.

The human resources management of the customs administration of Serbia pay a high attention to the risk analysis and assessment training and development delivered to the operational staff that is based on learning application of new IT software that is based on low, medium and high risk criterion for selective (high risk) search instead of 100 per cent search as well learning operational risk analysis and assessment skills. Therefore the customs administration focuses on investments in training and development activities in order to enable the enforcement teams to adapt, compete, excel, innovate, produce, be safe, improve operations, and reach goals (Salas, et al., 2012). This research aims to present the important impact of the human resource management of the customs administration of Serbia on improvement of the operational performances of the staff and on reaching the strategic goals; "Because of their value, the human resource is able to contribute to an organization's strategic objectives" (Lepak \& Snell, 2002: 520). For us, the relationship is more top-down. We would say, "When employees are able to contribute to an organization strategic objective, they have (strategic) value." In other words, human capital is only strategically important if it directly implements the organization's strategy (Lepak \& Snell, 2002:520).

The paper consists of four parts. The first part is related to the literature review regarding the interaction between the operational training and development and efficient operational performances. The second part of the paper explains the research methodology; the subject of the research, the aim of the research, the sample structure and the research instrument. The 
third part is reserved for the results of the research and discussion. Finally, the fourth part is the conclusion of the research.

The main purpose of this study is to research the effectiveness of risk analysis training of the customs officers on improvement of their operational performance at Belgrade Nikola Tesla airport. The objective is to measure the interaction between the operational training and the customs officers' operational efficiency at Belgrade Nikola Tesla airport.

\section{LITERATURE REVIEW}

Training and Development of the operational staff of any border agency basically deals with the acquisition of operational skills, understanding, know-how, operational techniques and practices. Therefore, training and development is one of the imperatives of human resource management in order to improve operational performance at individual, collegial and organizational levels of any border agency. In order to establish a process of 'increasing one's capacity to take action, the enforcement services and organizations are now increasingly becoming particular with operational learning and therefore collective development. Strategically, operational organizational learning, which makes use of training and development as one of the several responses, deals with the acquisition of understanding, know-how, operational techniques and practices. These intellectual intangibles can be translated into an organizational resource through the people that acquire, infer and utilize such towards the achievement of the organization-wide training and development (Armstrong, 2006). Operational training and development are planned undertaken activities based on learning experiences which teach operational staff how to perform current and future operations more effectively. Sims (2002) emphasizes that training focuses on present jobs while development prepares employees for possible future jobs. Basically, the objective of operational training and development is to contribute to improvement of operational performances in order to reach overall goal of the border agencies.

The aim of every border agency is to close the skills gap, which is now a critical area of human resource development for every enforcement organizations in order to continuously cope with the economic and trade globalization trends. Skills gap in every border agency presents a big treat to both the organizational and operational competencies and the economy, health and culture inheritance issues on a national level. Therefore, the human resource management professionals should start the training of the operational staff from the recruitment period. However, this is not easy considering that there are specific operational activities which require customization of various operational skills that in interaction with the operational (working) experience. In responding to the challenges of the skills gap and skills deficiency, HR professionals also have to develop programs that will address the problem (Sims, 2006).

Therefore, building the operational competencies is an imperative for the existence and survival of any modern organizations. Accordingly, border services are investing in their employees' skills thus taking advantage of the human capital management. The sense for the new operational skills development is also important, requiring $\mathrm{HR}$ professionals to develop strategies that will ensure superior 
operational practice, knowledge, skills and experience to settle within the staff. According to Sims (2006), learning activities shall put skills enhancement and development assignments at its core as well as empowerment and career development. This is lifelong learning which guide the organizations particularly human resource department to make an ongoing investment with organizational members and help them build their competencies. According to some authors, when an organization is undergoing change, the role of human resources role is to carry out the changes that are driven top down and initiated largely due to strategic business goals which the organization needs to achieve (Adeniji et al., 2013).

The purposes of learning from the employee perspective are basically to acquire skills and knowledge to do the job and to gain promotion and advance career. In facilitating career changes, training and development also caters for the personal and professional developments of the employees. Learning can be defined as knowledge obtained by self-directed study, experience, or both; the art of acquiring knowledge, skills, competencies, attitudes, and ideas retained and used; or a change of behavior through experience (Maycunich, 2000). Senge (1990) believes that learning has little to do with taking in information; rather it is a process that enhances capacity. Learning is about building the capacity to create that which one previously could not create.

In our days society is influenced and altered by the process of internalization and globalization. Globalization refers to a whole set of changes that puts a special and high importance on the work of human resources managers (Mura, 2012).

In fact, in the start of the twenty-first century Human Resource Managers have opined that one of the main challenges they are to confront had involved issues related to training and development (Stavrou, Brewster \& Charalambous, 2004).

\section{RESEARCH STRUCTURE AND RESULTS}

\subsection{Research Methodology}

This study used quantitative approach. Patton (2002) has argued that a qualitative research methodology can help researchers approach fieldwork without being constrained by any predetermined categories of analysis.

Moreover Gay, Mills and Airasian (2009) explained that the strength of quantitative research is the opportunities that it provides researchers to interact and gather data directly from their research participants to understand a phenomenon from their perspectives. On the other hand, qualitative research carries the uniqueness because it does not give conclusion in advance. It is often regarded as a scientific methodology of management sciences research (Taylor, 1998).

\subsection{Sample structure and size}

In the research, data were collected through a survey. In order to achieve the objectives of the research, 100 questionnaires were distributed among the customs officers at Nikola Tesla Airport. In response 90 questionnaires were returned. The response rate was $90 \%$.

As presented in Table 1, among all officers who were respondents, 90 of them or $100 \%$ were convenience and fixed sample. There were 45 customs officers who have 
Table 1. Research variables

\begin{tabular}{lcc}
\hline \multicolumn{1}{c}{ Variables } & $\xi$ & $\%$ \\
\hline Experimental group - & 45 & 50 \\
Control group - & 45 & 50 \\
Working experience & & \\
10 years & 48 & 53.3 \\
$10+$ years & 42 & 46.7 \\
Risk analysis and & & \\
assessment Training & & \\
$\quad$ & 45 & 50 \\
yes & 45 & 50 \\
\hline
\end{tabular}

acquired the risk analysis and assessment training (experimental group) and 45 customs officers who have not acquired the training (control group), out of which 48 officers have less than 10 years of working experience $(53.3 \%)$ and 42 officers with more than 10 years of working experience $(46.7 \%)$.

\subsection{Research instrument}

The questionnaire was designed on Likert 5 Rating Scale (1=Strongly Disagree, 2= Disagree, 3=Neutral, 4=Agree and $5=$ Strongly Agree). In order to measure the impact of the variables the data were analyzed through SPSS statistical analysis. The survey included grades of the officers' attitudes measured by 5-point Likert scale about their performance contribution in: revenue collection, facilitation of the trade and the flow of passengers, level of border control and protection and reputation.

\subsection{Data Collection}

The required information for the research was collected through questionnaire. The questionnaire is used in order to allow the respondents to answer in a standard way, with an unbiased approach and with a objective orientation. The use of questionnaire provides the information to be presented in a numeric way. Questionnaire method also has several limitations, for example lackadaisical attitude of respondents, non-attendance and lack of cooperation.

\subsection{Research results}

Descriptive statistics (Table 2) was used to analyze the difference of the officers' perceptions of their performance contribution in the operational results at the borders between the officers who attended the risk analysis and assessment training (the experimental group) and the officers who did not acquire the risk analysis and assessment 
Table 2 Descriptive Statistics - Mean and Standard Deviation

\begin{tabular}{|c|c|c|c|c|}
\hline \multirow[t]{2}{*}{ Statement } & \multicolumn{2}{|c|}{$\begin{array}{c}\text { Risk Analysis Training - } \\
\text { YES }\end{array}$} & \multicolumn{2}{|c|}{$\begin{array}{c}\text { Risk Analysis Training - } \\
\text { NO }\end{array}$} \\
\hline & Means & SD & Means & SD \\
\hline \multicolumn{5}{|l|}{$\begin{array}{l}\text { Contribution in collection of } \\
\text { revenue }\end{array}$} \\
\hline Collection of excise (S1) & 4.44 & 0.503 & 4.20 & 0.405 \\
\hline Contribution of customs duties (S2) & 3.91 & 0.557 & 3.64 & 0.484 \\
\hline \multicolumn{5}{|l|}{$\begin{array}{l}\text { Contribution in facilitation of the } \\
\text { traffic }\end{array}$} \\
\hline $\begin{array}{l}\text { Managing increasing volume of } \\
\text { passengers/trade vs. decreasing } \\
\text { (human) resources (S3) }\end{array}$ & 4.40 & 0.495 & 4.11 & 0.348 \\
\hline $\begin{array}{l}\text { Contribution in facilitation of trade } \\
\text { (S4) }\end{array}$ & 4.20 & 0.405 & 4.02 & 0.149 \\
\hline $\begin{array}{l}\text { Contribution in facilitation of flow } \\
\text { of passengers (S5) }\end{array}$ & 4.27 & 0.477 & 4.02 & 0.260 \\
\hline \multicolumn{5}{|l|}{$\begin{array}{l}\text { Contribution in the level of } \\
\text { border control and protection }\end{array}$} \\
\hline $\begin{array}{l}\text { Efficient fight against } \\
\text { smuggling/contraband (S6) }\end{array}$ & 4.33 & 0.477 & 4.11 & 0.438 \\
\hline $\begin{array}{l}\text { Efficient fight against organized } \\
\text { crime (S7) }\end{array}$ & 4.00 & 0.369 & 3.80 & 0.405 \\
\hline Efficient fight against terrorism (S8) & 4.42 & 0.499 & 4.22 & 0.420 \\
\hline \multicolumn{5}{|l|}{ Contribution to overall reputation } \\
\hline $\begin{array}{l}\text { Contribution to reputation in the eye } \\
\text { of other customs service (S9) }\end{array}$ & 4.33 & 0.477 & 4.11 & 0.438 \\
\hline $\begin{array}{l}\text { Contribution to general public } \\
\text { reputation (S10) }\end{array}$ & 4.38 & 0.535 & 4.16 & 0.424 \\
\hline
\end{tabular}

training (the control group). Encompassed statements were grouped into four groups: contribution in collection of revenues, contribution in facilitation of the traffic, contribution in the level of border control and protection and the contribution in overall reputation.

Independent Sample T-test is used to confirm the existing difference between the experimental and the control group related to: contribution in collection of excise , contribution in collection of customs duties, balance between the increasing volume of passengers/trade vs. decreasing (human) resources, facilitation of trade, facilitation of flow of passengers, efficient fight against smuggling/contraband, efficient fight against organized crime, efficient fight against terrorism, reputation in the eye of other customs service and reputation in the eye of general public (Table 3).

Factorial ANOVA is used to confirm the existing differences in evaluation depending on the length of the officers' working experience related to: collection of excise duty, customs duty, balance between the increased volume of passengers and trade vs. decreased (human) resources, facilitation of trade, facilitation of flow of passengers, efficient fight against smuggling and contraband, efficient fight against organized crime, efficient fight against terrorism, 
Table 3 Independent Sample t-test/ p value

\begin{tabular}{|c|c|c|}
\hline Statement & t value & p value \\
\hline \multicolumn{3}{|l|}{ Contribution in collection of revenues } \\
\hline Contribution in collection of excise & 2.542 & 0.013 \\
\hline Contribution in collection of customs duties & 2.424 & 0.017 \\
\hline \multicolumn{3}{|l|}{ Contribution in the facilitating the traffic } \\
\hline $\begin{array}{l}\text { Balance between the increasing volume of passengers/trade } \\
\text { vs. decreasing (human) resources }\end{array}$ & 3.292 & 0.002 \\
\hline Facilitation of trade & 2.766 & 0.008 \\
\hline Facilitation of flow of passengers & 3.169 & 0.002 \\
\hline \multicolumn{3}{|l|}{ Contribution in the level of control and protection } \\
\hline Efficient fight against smuggling/contraband & 2.302 & 0.024 \\
\hline Efficient fight against organized crime & 2.449 & 0.016 \\
\hline Efficient fight against terrorism & 2.055 & 0.043 \\
\hline \multicolumn{3}{|l|}{ Contribution to overall reputation } \\
\hline Reputation in the eye of other customs services & 2.302 & 0.024 \\
\hline Reputation in the eye in the general public & 2.185 & 0.032 \\
\hline
\end{tabular}

reputation among other customs services and reputation in eye of general public (Table 4).

\section{DISCUSSION OF THE RESULTS}

Evaluation of the training and development contribution in collection of the excise and customs duties

The descriptive statistics analysis in this research show that the experimental group evaluated the excise collected with the Mean of 4.44 and the standard deviation of 0.503 better than the collection of the customs duties with the Mean of 4.40 and the standard deviation of 0.455 . Since the control group evaluated the same statements in the same order (Table 2). It can be concluded that the officers evaluated the proportional improvement of the statements regarding the collection of revenues. The Independent Sample T-test, $p$ values of the statements also show that there is a significant difference in the level of the proportional improvement of the collecting of excise $(p=0.013)$ and collection of the customs duties $(p=0.017)$, that is shown in the Table 3. The ANOVA analysis shows that there were not significant statistical differences in perception of the training and development depending on the length of working experience of the officers in contribution in the collection of the excise $(p=0.469)$ and customs duty $(p=0.145)$. The research, accordingly, shows that there is a statistical difference in how the working experience and the training and development independently effects these two statements as individual factors. Therefore, there is a difference in the perception on the different impact for the contribution in the collection of excise $(p=0.17)$ and there is not a significant difference $(p=0.145)$ in perception of different impact of these two factors with regard to the contribution in the collection of the customs duty (Table 4).

\subsection{Evaluation of the traffic flow}

The evaluation of the contribution on flow of traffic was based on assessing the balance between the increasing volume of traffic and 
Table 4. Factorial ANOVA

\begin{tabular}{lllllllllll}
\hline Statement & S1 & S2 & S3 & S4 & S5 & S6 & S7 & S8 & S9 & S10 \\
\hline $\begin{array}{l}\text { Length of } \\
\text { working } \\
\text { experience }\end{array}$ & 0.469 & 0.280 & 0.366 & 0.055 & 0.076 & 0.520 & 0.661 & 0.450 & 0.027 & 0.037 \\
$\begin{array}{l}\text { Groups *. } \\
\text { working } \\
\text { experience }\end{array}$ & 0.017 & 0.145 & 0.009 & 0.008 & 0.214 & 0.002 & 0.082 & 0.000 & 0.027 & 0.471 \\
\hline
\end{tabular}

* Statistical significance $p<0.05$

decreasing (human) resources, facilitation of the trade and facilitation of the flow of passengers.

The descriptive statistics analysis shows that the experimental group evaluated the balance between the increased volume of traffic and decreasing (human) resources the best, with the Mean of 4.40 and the standard deviation of 0.495 . The second ranged is the facilitation of the flow of passengers with the Mean of 4.27 and the standard deviation of 0.477 . The facilitation of trade was scored with the Mean of 4.20 and the standard deviation of 0.405 . On the other hand, the control group evaluated the balance between the increasing volume of traffic and decreasing (human) resources with best grades as well with the Mean of 4.11 and the standard deviation of 0.348 , while the facilitation of trade is scored with the Mean of 4.02 and the standard deviation of 0.149 and the facilitation of the flow of passengers with the Mean of 4.02 and the standard variation of 0.260 . Considering the lower level of the standard variation, it can be stated that the facilitation of trade is better scored than the facilitation of the flow of passengers by the control group (Table 2). The Independent Sample T-test shows that there is a significant difference between these two groups in the perceived contribution in the balance between increased volume of traffic and decreased (human) resources $(p=0.002)$, facilitation of the trade $(p=0.008)$, and the facilitation of the flow of passengers $(p=0.002)$ that is shown in the Table 3. Regarding the evaluation of the influence of length of working experience in on the evaluation of the officers, the Factorial ANOVA results show that there is not a significant difference in increased volume of trade and passengers and the decreased (human) resources $(p=0.366)$, facilitation of trade $(p=0.055)$ and the facilitation of the flow of passengers $(p=0.076)$, meaning that the length of working experience does not have a significant impact on the perception of these two groups. The factorial ANOVA shows that the working experience and the training do not affect the perception as two independent factors on the equal level, meaning that there is a significant difference in the balance between the increased volume of trade and passengers and the decreased (human) resources $(p=0.009)$ and facilitation of trade $(0.008)$ but not a significant difference (0.0214) for the facilitation of the flow of passengers (Table 4). 
4.2. Evaluation of contribution in control and protection level

Regarding the results of the descriptive statistics analysis in this research related to the control and protection level, the experimental group evaluated efficient fight against terrorism with the Mean of 4.42 and the standard deviation of 0.499 better than the fight against smuggling and contraband with the Mean of 4.33 and the standard deviation of 0.477 and the fight against organized crime with the Mean of 4.00 and the standard deviation of 0.369 . On the other hand, the control group evaluated all three statement in the same order; fight against terrorism with the Mean of 4.22 and the standard deviation of 0.420 , fight against smuggling and contraband with the Mean of 4.11 and the standard deviation of 0.438 and the fight against organized crime with the mean of 3.80 and the standard deviation of 0.405. According to the Independent T- test analysis, the $p$ values of the statements from both groups show that there is the most significant difference in the evaluation of the fight against organized crime $(p=0.16)$, than the fight against the smuggling and contraband $(p=0.024)$ and the least significant difference is in the evaluation of the fight against terrorism $(\mathrm{p}=0.043)$ shown in the Table 2 and 3. The Factorial ANOVA analysis shows the length of working experience does not have a significant influence on the officers perception on the fight against smuggling and contraband $(p=$ 0.520 ), effective fight of the organized crime $(p=0.661)$ and the effective fight against terrorism $(p=0.450)$ while there is the significant difference in how training and the working experience influence the officers' perception of the effective fight against smuggling and contraband $(p=0.002)$ and of the effective fight against terrorism $(p=0.000)$ but not a significant difference $(p=0.082)$ in the impacts on the effective fight against organized crime (Table 4).

\subsection{The evaluation of the contribution to the overall reputation}

The results of the descriptive statistics analysis in this research show that the evaluation of the officers related to reputation in the eye of general public with the Mean of 4.38 and the standard deviation of 0.535 that is better evaluated than the reputation among other customs services with the Mean of 4.33 and the standard deviation of 0.477 . Regarding the control group, the evaluation of these two statement is in the same order; reputation in the eye of general public with the Mean of 4.16 and the standard deviation of 0.424 and the reputation among other customs services with the Mean of 4.11 and the standard deviation of 0.438 , meaning that the improvement was evaluated as linear that was confirmed by the $p$ values (Table 3 ) from the Independent T-test analysis of the evaluation of the statements from both groups showing that there is the less significant difference in evaluating reputation among other customs services $(p=0.032)$, than the statement related to reputation in the eye of general public $(p=0.024)$, that further confirms the evaluation difference between these two groups. Regarding the evaluation of the influence of the length of working experience on the evaluation, the Factorial ANOVA results show that there is a significant influence of the working experience on officers' perception of reputation among other customs services $(\mathrm{p}=$ 0.027 ), but not a significant influence on 
evaluating the reputation in the eye of general public $(p=0.931)$. There is a significant difference in how the training and the working experience influence the officers' perception in evaluation of reputation among other customs services $(p=0.027)$ and not a significant difference in how the training and the working experience as two separate factors influence the officers' perception in evaluation of the reputation in the eye of general public $(p=0.471)$, that is shown in the Table 4.

The main limitations of this research are the size of the sample and that the research does not include the customs units from all border crossing points in Serbia that is reserved for the next study.

\section{CONCLUSION}

A great number of empirical studies show that HRM has positive relationship on performance of an organization and also can be source of sustainable competitive advantage to the organization (Beh \& Loo, 2013). In nowadays constant changes of the trends in increasing volume of passengers, methods of smuggling and human trafficking, on the one, and decreasing technical and human resources, on the other hand is the main challenge for the operational staff at border crossing point at the airport. In order to keep a step with all those constant changes and challenges, the sustainability of the customs service and the balance between the free mobility and circulation of passengers and the prevention of the trans-border crime, the constant training and development of the operational staff is an imperative.

The human resources management of the customs administration of Serbia has always played a main role in improvement of the operational performance of the service as a whole, especially at the border crossings by constant training and development and the effective deployment of the staff, especially during the last two decades of very dynamic administrative and political changes. According to Adeniji et al (2013), the term of Human Resource Management refers to design and applications of formal system in an organization to ensure effective and efficient use of human talent for achieving goals of the organization. Hence, IT training and development of the operational staff at the border crossings is one more indication of the constant development and innovation of human recourses training and development methodology and strategies.

The first contribution of this research is the conceptual model of the study that tested the relationship between HRM best practices and the organization performances at the organizational level. The second contribution is the demonstration of the impact of the strength of the HRM best practice on operational performances of the organization (Beh \& Loo, 2013).

\section{References}

Adeniji, A.A., Osibanjo, O.A., \& Abiodun, A.J. (2013). Organizational change and human resource management interventions: an investigation of Nigerian banking industry. Serbian Journal of Management, 8(2),139-154.

Armstrong, M. (2006). A Handbook of Human Resource Management Practice, London, UK: Kogan Page, Ltd.

Beh, Loo-See., \& Loo, Leap-Han. (2013). Human resource management best practices and firm performance: a universalistic 
perspective approach. Serbian Journal of Management, 8(2),135-167.

Gay, L. R., Mills, G. E., \& Airasian, P. (2009). Educational research: Competencies for analysis and applications. London: Pearson.

Gilley, J. W., \& Maycunich, A. (2000). Beyond the Learning Organization: Creating a Culture of Continuous Growth and Development through State-Of-The-Art Human Resource Practices. Cambridge, MA: Perseus Books.

Hameed, A., \& Waheed, A. (2011). Employee Development and Its Affect on Employee Performance Framework. International Journal of Business and Social Science, 2 (13), 224-229.

Lepak, D. P., \& Snell, S. A. (2002). Examining the human resources architecture: The relationships among human capital, employment and resource configurations. Journal of Management, 28(4), 517-543.

Mahyuddin, M. Y. (2009). The Effectiveness of Training in the Public Service, American Journal of Scientific Research, 6 (2009), 39-51.

Mura, L. (2012). Performance of Human Resource Management in an internationally operating company. Serbian Journal of Management, 7(1),115-129.

Niazi. A.S., (2011). Training and Development Strategy and Its Role in Organizational Performance, Journal of Public Administration and Governance, $1(2), 42-57$.

Patton, M. Q. (2002). Qualitative research \&evaluation methods. Thousand Oaks, CA: Sage Publications.

Salas. E., Tannenbaum, S. I., \& Kraiger K. (2012). The Science of Training and

\title{
УТИЦАЈ ОБУКЕ НА ОПЕРАТИВНЕ ПЕРФОРМАНСЕ: СЛУЧАЈ ЦАРИНСКЕ СЛУЖБЕ НА АЕРОДРОМУ НИКОЛА ТЕСЛА БЕОГРАД
}

\author{
Сања Далтон
}

\begin{abstract}
Извод
У овом раду предтстављен је утицај обуке анализе и процене ризика на унапређење оперативних перформанси царинских службеника на аеродрому Никола Тесла Београд. Циљ итраживања је мерење перцепције царинских службеника на аеродрому у вези са оперативном ефикашношћу програма обуке анализе ризика. Истраживање је спроведено кроз анкету, прикупљањем података из упитника подељених царинским службеницима који су били подељени у експерименталну (цариници који су похађали обуку) и контролну групу (цариници који нису похађали обуку). Обе групе цариника су оценили исказе везано за њихов допринос ефективном убирању прихода, олакшавању протока робе и путника, ниво граничне контроле и заштите и репутацију царинске испоставе на аеродрому. Резултати истраживања показују да постоји значајна разлика између ове две групе, што потврђује хипотезу да обука анализе и процене ризика има позитиван утицај на оперативну ефикасност царинских службеника.
\end{abstract}

Кључне речи: Обука, оперативна перформанса, анализа ризика, царинска служба 
Development in Organizations: What

Matters in Practice, University of Center

Florida.

Senge, P. M. (1990). The Fifth Discipline: The Art and Practice of the Learning Organization. New York: Doubleday.

Sims, R. (2002). Organizational Success through Effective Human Resources Management. Westport CT: Quorum Books.

Sims, R. S. (2006). Human Resource Development: Today and Tomorrow. IAP.

Stavrou, E., Brewster, C., \& Charalambous, C. (2004). Human Resource Management as a Competitive Tool in Europe, working paper, London: Henley College.

Taylor, S. J., \& Bogdan, R. (1998). Indepth interviewing. Introduction to qualitative research methods: a guidebook and resource, 87-116. 